\title{
Librarian's Roles on Students Who are Hurt: A Comparative Study of Two Countries
}

\author{
Dr. Fadekemi Oyewusi \\ College of Education \\ East Carolina University \\ fdkwusi@yahoo.com \\ Dr. Maria Fe S. Nicolau \\ BINUS School Simprug \\ nicolau@binus.edu
}

\author{
Dr. Kolawole Akinjide Aramide \\ kolaakinjide@gmail.com \\ University of Ibadan
}

\section{Mrs. Francisca A. Messakh \\ franciscamessakh@gmail.com}

Keywords: Bibliotherapy, Hurting students, School librarian, Nigeria, Indonesia

\begin{abstract}
Librarians are re-discovering themselves in many functions that connects them to library users by playing critical roles in supporting the users. Investigating how librarians will help their users is now significant to school library services. This is a comparative study carried out in Nigeria and Indonesia to find out roles of librarians towards helping hurting library users.

The study investigates if librarians are aware of the issues that makes their users hurts emotionally and if there are specific activities that are created in the libraries to enhance users' well-being. The librarians in these two countries were asked if they use readers' advisory to recommend literature that could help users that are hurting. This study also examines wether librarians in these countries understands the concept of bibliotherapy.
\end{abstract}

Every librarian has the potential to help hurting library users once they recognise the efficacy of using the appropriate book to help. The 21st century library professionals need to learn more about their potentials to help and comfort users in the library space.

\section{Introduction}

The $21^{\text {st }}$ century librarians explore different approaches to sustain the appealing atmosphere of the library. Not only do they build collections to meet the changing demands of the community but they also participate in ways to help students cope with their personal (e.g. bullying, stress, identification) and 
family problems (e.g divorce, family dysfunction). One of the widespread practices that librarians could explore is the use of bibliotherapy. Bibliotherapy as a psychosocial intervention has benefits on increasing the coping skills of children who have experienced a traumatic event, and can combine the use of literature with helping children overcome problems and facilitating healthy growth. (De Vries, et al., 2017).

Every librarian has the potential to develop the reading interest of hurting library users by recommending and providing reading materials that can ease their feelings and alleviate the discomfort they are experiencing. This current comparative study between the librarians from Nigeria and Indonesia aims to explore the awareness of librarians on issues involving students who are emotionally hurt and to identify the specific activities created in the libraries that support their well-being. It further aims to investigate the extent of book purchasing, the use of readers' advisory, the understanding of the term bibliography and the changes made in the school library space and facilities to make the area more inviting and stress-free.

\section{Statement of the Problem}

Bibliography is an evidence-based treatment strategy for a wide variety of psychological concerns which most librarians and library users are not aware about. Children might experience severe psychological and emotional problems, such as depression, anxiety, loneliness, low self-esteem, multiple deaths in their families and go through bereavement (Tukhareli, 2013). Severe psychological and emotional problems could lead to suicidal tendecies among young people. Hence, librarians need to begin to use this strategy because some children come to the library to find solution to their emotional traumas without knowing that the library can provide book therapy for their hurting emotions. This comparative study provides possible framework to help librarians find out their role towards helping library users who are hurt. Specifically in responding to the following research questions:

1. What issues are the librarians aware of that hurts the students?

2. What are the specific spaces available in the library that enhance students' well- being and care?

3. What is the extent of librarians' understanding about bibliotherapy?

4. How much impact do librarians have in providing care-based practices on student well-being in the school?

5.What changes are made in the school library space/facility to address students' overall wellbeing?

\section{Review of Literature}

The term "bibliotherapy" goes back to the beginning of the twentieth century, when Crothers (1916) coined the term. It is made up of two words originating from the Greek word biblus meaning book, and therapy, referring to psychological help. Simply stated, bibliotherapy can be defined as the use of books to help readers solve problems which helps them understand their perplexed emotions. Jones (2006) describes bibliotherapy among youth as a process that leads youth toward emotional health through the medium of literature. In today's visually stimulating environment of films, smart - phones, computers, short stories (Dowrick et al., 2012) and graphic novels have become popular among the youth as appealing forms of literature. Thus, literature serves as a tool and a catalyst in the process of change and healing.

There are many reasons why young people in today's world hurt. According to Harper (2017), youth health is most likely to be negatively impacted from the following factors like prior history of violence, drug, alcohol, or tobacco use, association with delinquent peers, poor family functioning, poor grades in

International Association of School Librarianship

https://iasl-online.org 
school, and poverty in the community. Young people with emotional and behavioural problem are likely to be destructive, misbehave and have problem with coping with socially acceptable behaviour (Adeyeye and Oyewusi, 2017). These young people who have behaved unruly are more likely to commit crime which would take them to correctional homes. If these reasons are not taken care of the world will have more suicides, mass killings, bullying etc carried out by these young people and this will make the world unsafe for every. Hence, the need to use other strategies like bibliotherapy to help out. So the librarian comes to the rescue!

According to Tielsch Goddard (2011), books selected for bibliotherapy should present motivating and challenging experiences, reveal critical and personal answers and develop a sense of respect and understanding differences. Orlando (2017) commented that when exploring bibliography the materials are carefully chosen books, self - help manuals, e-learning programs and fiction or poetry. In her study, she concluded that $79 \%$ of counsellors used bibliotherapy mainly in the form of non-fiction self-help manuals and $78 \%$ books and a noticeable improvement in their patients' mental health and stability was observed. The use of relevant books may bring behaviour modifications and turn around positive changes. Bibliotherapy can be most effective when utilized with the direction of a library professional rather than volunteer staff or someone not knowledgeable about library work.

\section{Methodology}

The descriptive research design of the ex-post facto type was adopted for the study. The target audience for the study were school librarians working within the school setting and relating with pupils and secondary school students. This comparative study is completed by surveys distributed to the librarians in Nigeria and Indonesia. It was carried out to find out the roles of librarians on students who are hurt. The researchers in these two countries started by putting the survey questions in google forms in July 2018 and the link was mailed to the List Serv of librarian groups in the two countries. The questionnaire designed for the study was composed of two sections. Section A was focused on collecting data on the demographic information of the respondents such as type of school and qualification of the respondents while Section B was designed to gather data on issues relating to the role of librarians in treating hurting students as well as their knowledge of bibliotherapy.

After three months, there was a very low response of the survey sent to the librarians in each country. The researchers decided to distribute printed copies of the survey to the participants during the $33^{\text {rd }}$ Annual conference of the Nigeria School Library Association (NSLA) which was held in October 2018 at Abuja and the Information Literacy Conference which happened in December 2018 in Bekasi, Indonesia. The NSLA Conference (Nigeria) and the Information Literacy Conference (Indonesia) are annual events that brings together school librarians, education officers, researchers and other stakeholders who specializes in school librarianship development. To ensure that only school librarians were the selected respondents, research assistants were carefully instructed on how to collect the data using the snowball method. A total of forty-seven copies of questionnaire were returned out of which 42 were found useable for the study from Nigeria while 40 copies of questionnaire were returned from Indonesia. The filled in survey forms were given back to the researchers to save time in collecting the data. Data were collated and interpreted using tables, frequencies, percentage and bar charts.

\section{Findings and Discussion}

School are owned by different organizations and establishments in different countries, these could either be private or public and this applies to the libraries within the schools. This study therefore, sought to know the demographic of the respondents involved in the study by finding out the organisation that owns

International Association of School Librarianship

https://iasl-online.org 
their school. The result (Figure 1) showed that there were 18 (42.5\%) from Nigeria and 17 (42.5\%) from Indonesia that works in K-12 private (or chartered) schools, $5(11.9 \%)$ researchers from Nigeria and $6(15 \%)$ from Indonesia in private schools owned by universities. Other schools were also owned by government or public universities in both countries (Figure 1). In addition, all the respondents are professionally qualified with degrees of varying levels in library studies (e.g. certified librarians, degree in library studies, master's in library studies and Doctorate in Library Studies).

Figure 1: Type of workplace of school librarians from Nigeria and Indonesia

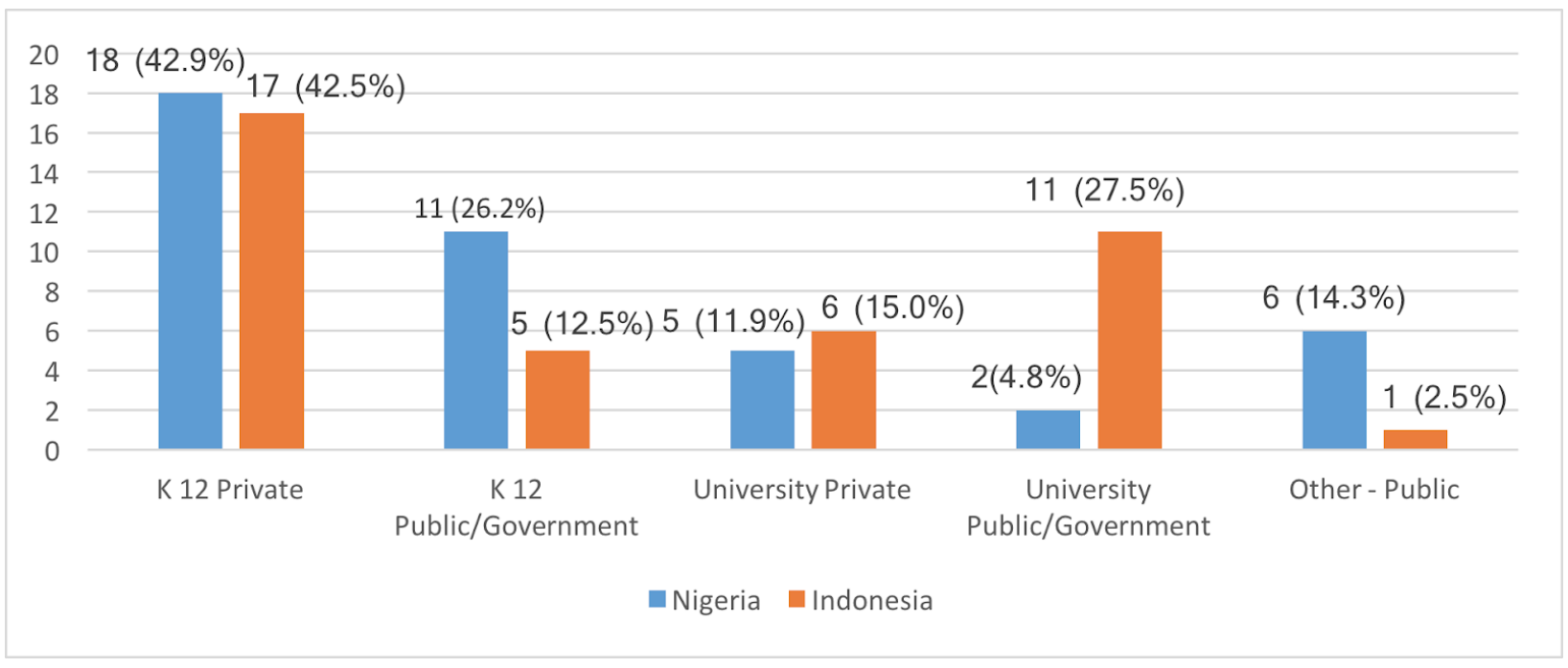

A few options were designed to find out issues that hurts students in Nigeria and Indonesia. Figure 2 shows the data. The five major issues that hurt students who are library users as seen in the study from Nigeria are poverty (34 or $81.0 \%$ ) bullying (29 or $69.0 \%$ ), family dysfunction ( 27 or $64.3 \%$ ), school violence (22 or $52.4 \%$ ), mental health (21 or $50.0 \%)$. In Indonesia, issues are bullying (29 or $72.5 \%)$, mental health (18 or $45.0 \%)$, poverty (12 or 30.0\%), recent death (10 or $25.0 \%)$ and school violence (8 or $20.0 \%$ ). While there are some common issues (poverty, bullying, mental health, school violence) shared by both countries, it can be inferred from the results that the students in Nigeria have more hurting issues especially poverty than those in Indonesia.

This could be because Nigeria emerged from recession in 2017 , with a growth rate of $0.8 \%$, driven mainly by the oil sector and it still fell below the population growth rate, government projections and pre-recession levels in recent time (World Bank, 2019). According to World Bank (2019), the Nigerian oil sector is likely to stagnate in the face of regulatory uncertainty, limiting investments in the sector while her Agriculture may remain affected by conflicts and climate and weather events. Whereas, Indonesia is the world's 10th largest economy in terms of purchasing power parity, a member of the G-20 and an emerging middle-income country (World Bank, 2019). World Bank also reiterates that Indonesia has made enormous gains in poverty reduction, cutting the poverty rate to more than half since 1999 , to $9.8 \%$ in 2019. Thus, school libraries can play a fundamental role through strategic services (like bibliotherapy) they offer to create opportunities for learning, supporting literacy and education that will help promote better socio-economic status and could relegate trauma among young people. Harper (2017) also agrees that poverty is at the heart of many of the issues experienced by youth worldwide. 
Figure 2: Issues that hurt the students in Nigeria and Indonesia

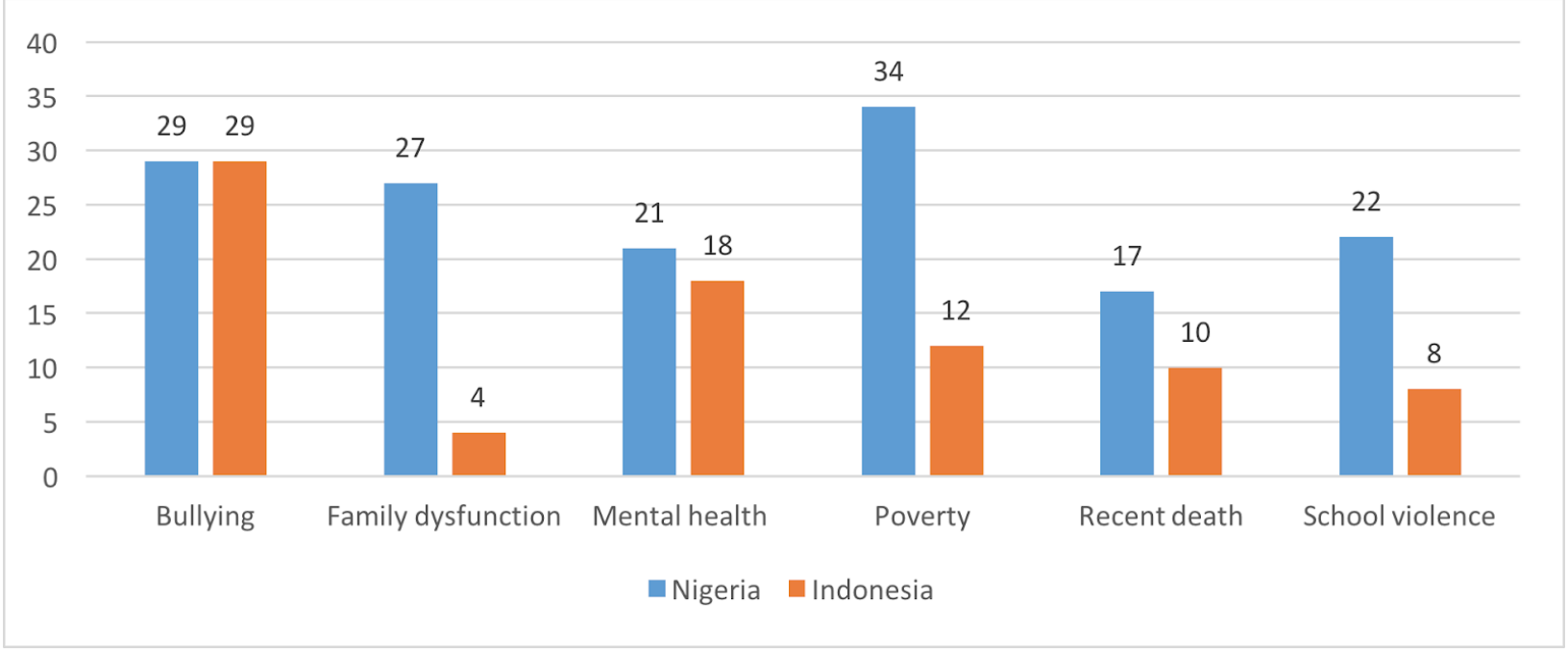

There were common spaces of activities created in school libraries in both countries that could help hurting students and this study asked the respondent if they had any of these spaces (Figure 3). In Nigeria, provided spaces include quiet areas (27 or $64.3 \%$ ), display of different topics (25 or 59.5\%), private reading areas (21 or $50.0 \%)$, makerspace (15 or 35.7\%) and space to relax (14 or $33.3 \%)$. On the other hand, responses from Indonesia shows that spaces provided in the library are private reading areas and quiet areas (25 or 62.2\%), place to relax and display of different topics ( 24 or $60.0 \%)$ and safe haven (11 or $27.5 \%$ ). The result, as shown in Figure 3, reveals that quiet areas, display of different topics, private reading areas and space to relax are commonly available in the school libraries in both countries. The lack of haven space is a concern in school libraries in Nigeria while makerspace is not common in the Indonesian school libraries. 
Figure 3: Spaces for activities in the school library in Nigeria and Indonesia

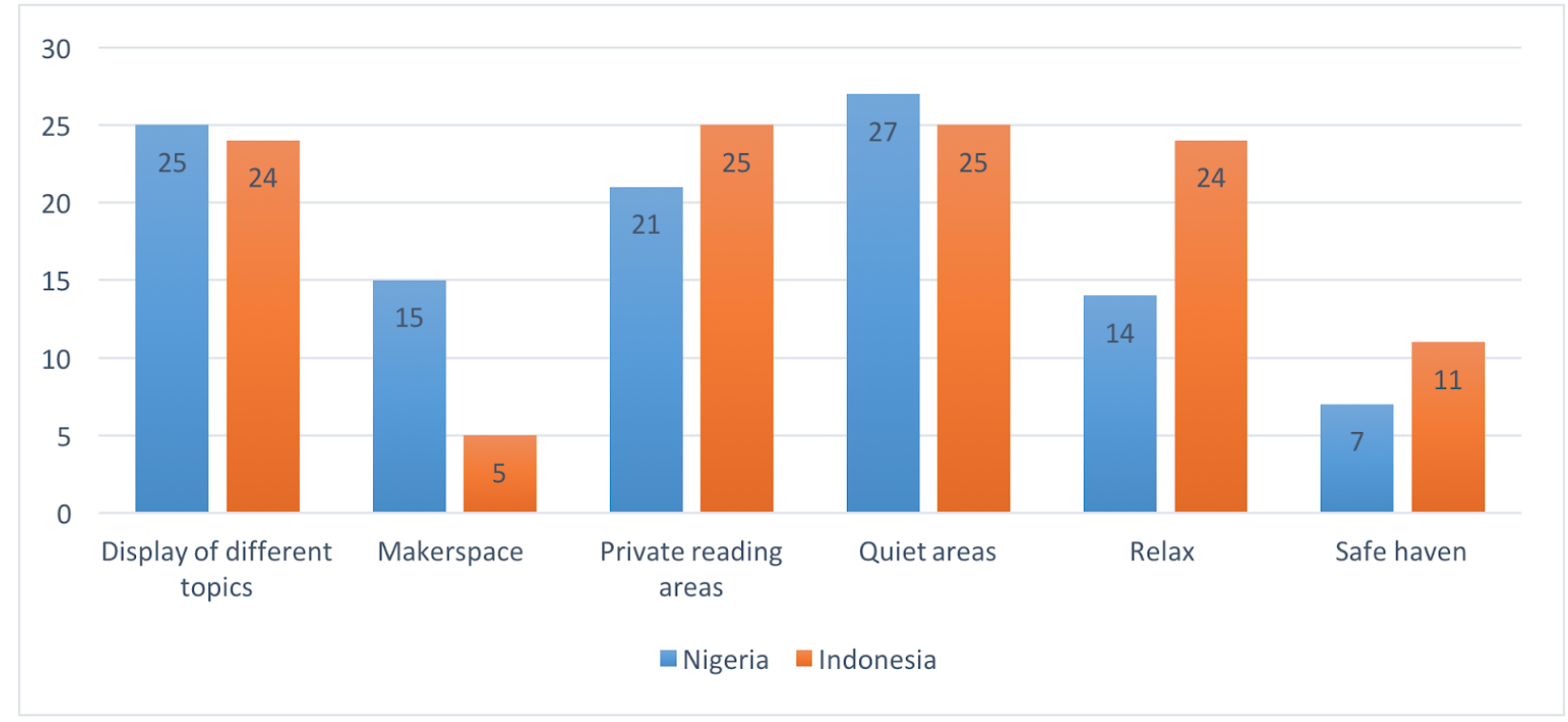

School librarians in both countries were asked if they had an idea what bibliotherapy was about. The result revealed that school librarians in Nigeria (23 or 54.8\%) and Indonesia (23 or $57.5 \%$ ) are aware of bibliotherapy. However, they do not have adequate knowledge of how to implement it to address issues arising among students making use of their school libraries. According to Harper (2017), a school librarian positively affects students' feelings of being cared for and how thoughtfully designed instruction, collocation of a collection, and the school library facility all contribute to helping students who hurt. Yet, when asked, many school librarians offer multiple anecdotal accounts of touching a child one heart at a time and of creating a safe, enriching environment based on understanding the needs of the whole child and not just for the purpose of supporting the curriculum (Harper, 2017). This study shows that these librarians do not know how to go about using bibliotherapy to achieve helping hurting student though they are concerned. Librarians need to explore the opportunity of using optimistic effects of book reading on healing, health and wellbeing.

Figure 4: School librarians' awareness on bibliotherapy in Nigeria and Indonesia

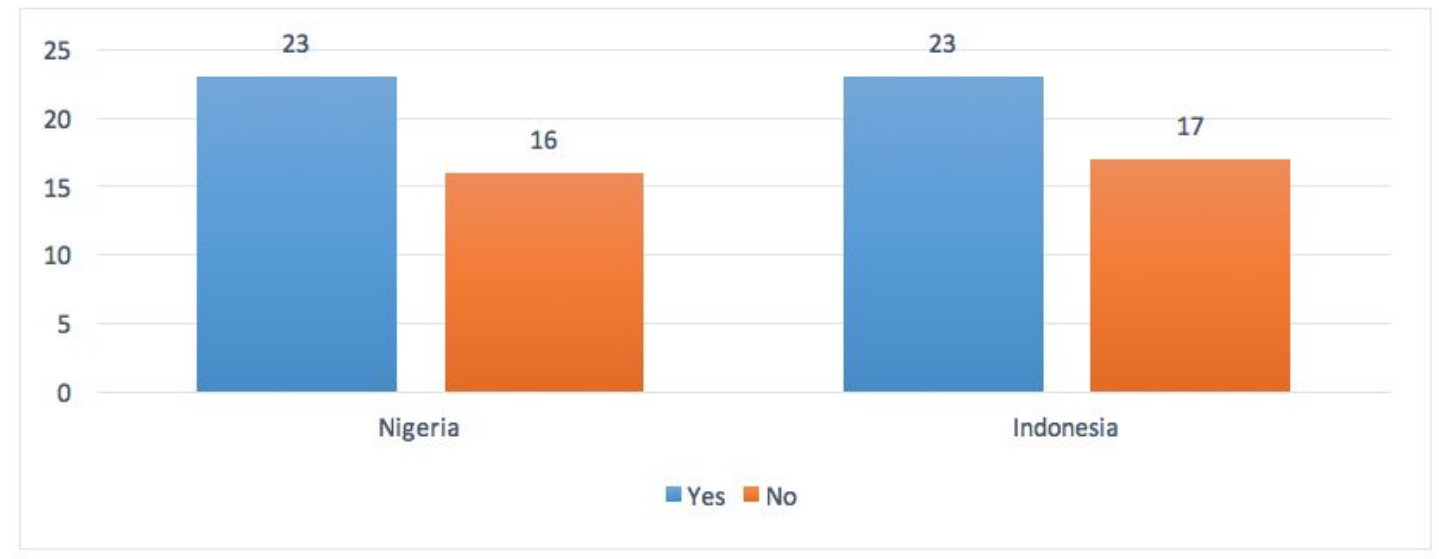


There were questions for school librarians in both counties on care-based practices relating to student's well-being. Figure 5 shows that the school librarians in Nigeria have the opinion that care-based practices relating to student's well-being had moderate impact (31 or $73.8 \%$ ) followed by those who think this had no impact (11 or $26.2 \%$ ). However, no school librarian thought care-based practices relating to student's well-being had a major impact. On the other hand, 29 (72.5\%) school librarians from Indonesia feels that the care-based practice has moderate impact followed by $7(17.4 \%)$ who feels there is no impact and lastly $4(0.1 \%)$ who are of the opinion that there was a major impact. Seemingly, school librarians in Nigeria and Indonesia demonstrate the same pattern of awareness of care-based practices from moderate, to no impact and finally major impact and this can be traced back to their level of consciousness on the implementation of bibliotherapy.

Figure 5: Opinion of school librarian on impact of care-based practices relating to student's well-being

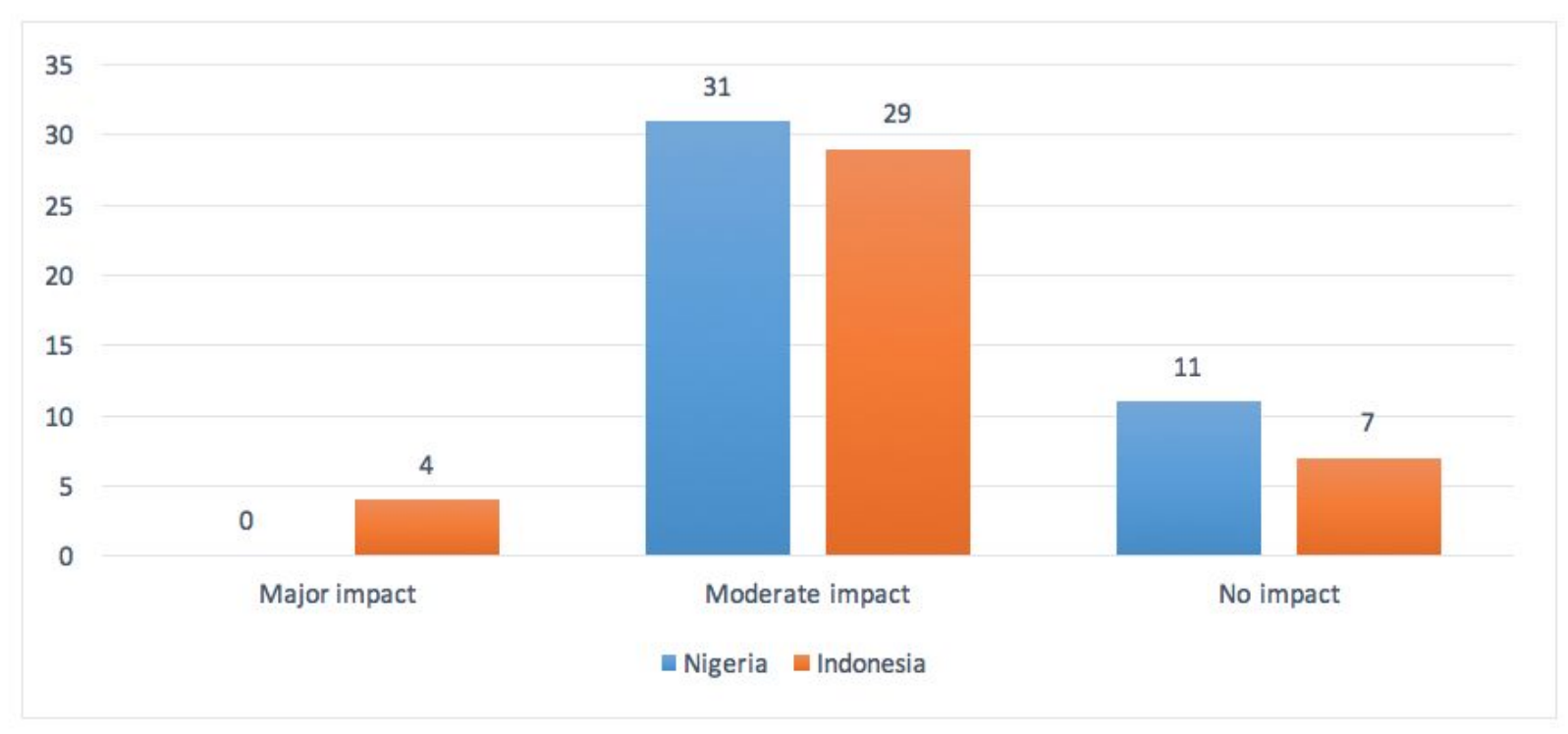

To find out the changes made in the school library spaces in Nigeria and Indonesia that could help hurting students, the opinions of the respondents were sought through the following questions shown in Table I. Both countries rated their responses moderate in term of the changes made in the library. Specifically, moderate changes were done to support spaces for students to increase collaborative learning (Nigeria: 20 or $47.6 \%$ and Indonesia: 18 or $45.0 \%$ ), to privately select and use informational materials on social and emotional issues (Nigeria: 18 or $42.9 \%$ and Indonesia:18 or $45.0 \%$ ), to support spaces for students to relax (Nigeria: 13 or $30.9 \%$ and Indonesia: 18 or $45.0 \%$ ). On the other hand, school librarians in Nigeria also rated moderate on spaces for students to be alone (22 or 52.4\%) and to display resources that include current issues and topic facing students (19 or 45.2\%) while Indonesia showed an extensive space for students to be alone (17 or $42.5 \%$ ) and a limited space for display of resources (19 or $47.5 \%$ ).

This suggests that school librarians from both countries, observe common practices in terms of provision of spaces in the library; however, the value of providing a space for displaying the resources that include current issues and topic facing students specifically in Indonesia are highlighted to help those who are hurt. Librarians can design the library as a space in which students can experience being cared for and access to resources, instruction, and opportunities that aid them in coping with stressful or painful situations (Harper, 2017). 
Table 1: Changes made in the school library spaces in Nigeria and Indonesia

\begin{tabular}{|c|c|c|c|c|c|c|c|c|}
\hline Country/Response & Nigeria & Indonesia & Nigeria & Indonesia & Nigeria & Indonesia & Nigeria & Indonesia \\
\hline Library spaces & \multicolumn{2}{|c|}{ Extensive } & \multicolumn{2}{|c|}{ Moderate } & \multicolumn{2}{|c|}{ Limited } & \multicolumn{2}{|c|}{ Not at all } \\
\hline $\begin{array}{l}\text { A space displaying } \\
\text { the resources that } \\
\text { include current issues } \\
\text { and topic facing } \\
\text { students }\end{array}$ & $\begin{array}{c}9 \\
(21.4 \%)\end{array}$ & $\begin{array}{c}5 \\
(12.5 \%)\end{array}$ & $\begin{array}{c}19 \\
(45.2 \%)\end{array}$ & $\begin{array}{c}13 \\
(32.5 \%)\end{array}$ & $\begin{array}{c}2 \\
(4.8 \%)\end{array}$ & $\begin{array}{c}19 \\
(47.5 \%)\end{array}$ & $\begin{array}{c}7 \\
(16.6 \%)\end{array}$ & $\begin{array}{c}3 \\
(7.5 \%)\end{array}$ \\
\hline $\begin{array}{l}\text { A space for students } \\
\text { to be alone }\end{array}$ & $\begin{array}{c}3 \\
(7.1 \%)\end{array}$ & $\begin{array}{c}17 \\
(42.5 \%)\end{array}$ & $\begin{array}{c}22 \\
(52.4 \%)\end{array}$ & $\begin{array}{c}5 \\
(12.5 \%)\end{array}$ & $\begin{array}{c}10 \\
(23.8 \%)\end{array}$ & $\begin{array}{c}13 \\
(32.5 \%)\end{array}$ & $\begin{array}{c}7 \\
(16.7 \%)\end{array}$ & $\begin{array}{c}5 \\
(12.5 \%)\end{array}$ \\
\hline $\begin{array}{l}\text { A space for students } \\
\text { to relax }\end{array}$ & $\begin{array}{c}4 \\
(9.5 \%)\end{array}$ & $\begin{array}{c}10 \\
(25.0 \%)\end{array}$ & $\begin{array}{c}13 \\
(30.9 \%)\end{array}$ & $\begin{array}{c}18 \\
(45.0 \%)\end{array}$ & $\begin{array}{c}12 \\
(28.6 \%)\end{array}$ & $\begin{array}{c}10 \\
(25.0 \%)\end{array}$ & $\begin{array}{c}13 \\
(30.9 \%)\end{array}$ & $\begin{array}{c}2 \\
(5.0 \%)\end{array}$ \\
\hline $\begin{array}{l}\text { A space for student to } \\
\text { select and use } \\
\text { informational } \\
\text { materials on social } \\
\text { and emotional issues } \\
\text { privately }\end{array}$ & $\begin{array}{c}4 \\
(9.5 \%)\end{array}$ & $\begin{array}{c}3 \\
(7.5 \%)\end{array}$ & $\begin{array}{c}18 \\
(42.9 \%)\end{array}$ & $\begin{array}{c}18 \\
(45.0 \%)\end{array}$ & $\begin{array}{c}8 \\
(19.0 \%)\end{array}$ & $\begin{array}{c}19 \\
(47.5 \%\end{array}$ & $\begin{array}{c}12 \\
(28.6 \%)\end{array}$ & $\begin{array}{c}0 \\
(0.0 \%)\end{array}$ \\
\hline $\begin{array}{l}\text { A space for } \\
\text { collaborative learning }\end{array}$ & $\begin{array}{c}5 \\
(11.9 \%)\end{array}$ & $\begin{array}{c}17 \\
(42.5 \%\end{array}$ & $\begin{array}{c}20 \\
(47.6 \%)\end{array}$ & $\begin{array}{c}18 \\
(45.0 \%)\end{array}$ & $\begin{array}{c}11 \\
(26.2 \%)\end{array}$ & $\begin{array}{c}5 \\
(12.5 \%)\end{array}$ & $\begin{array}{c}6 \\
(14.3 \%)\end{array}$ & $\begin{array}{c}0 \\
(0.0 \%)\end{array}$ \\
\hline
\end{tabular}

\section{Conclusions}

Bullying and issues from poverty are major issues that commonly hurts students in Nigeria and Indonesia as seen in responses of school librarians and one the recommended innovative approach to help them is through bibliotherapy. Bibliotherapy can be used as an alternative treatment or at least an adjunct therapy method in order to combat the stress and angst levels caused by the family and immediate environment. The consequences of bullying and poverty among other vices on the physical and psychological well-being of young people are serious and worthy of attention (Dali, 2018; Harper, 2017; Becnel, 2007). Despite the fact that school librarians in both countries (Nigeria and Indonesia) recognize the provision of library spaces for private reading, quiet areas and collaborative learning to help the students who are hurt through the healing power of books, the need for spaces in displaying the resources that include current issues and topic facing students need to be evaluated.

School librarians should be taught about the process of bibliotherapy and its strategies like library collection development, programs and services to help students who are hurt in schools. As Quzts and Palombo (2005) mentioned bibliography helps in the healing of the soul. Its effective technique can be used by school librarians to promote mental health and physical health which could reduce disruptive 
behaviours of vulnerable children and young people. Hence, they can make sense of their lives by not hurting themselves or other people. In a different context, the authors acknowledged the limitation of the study by focusing solely on the descriptive survey. Further research can be conducted to explore the qualitative aspect on how librarians can use bibliotherapy in providing reader's advisory service to students who are hurt.

\section{REFERENCES}

Adeyeye, S. and Oyewusi, F. O. (2017). Effects of bibliotherapy on unruly behavior of juveniles in correctional homes. Presented at the 45th International Association of School Librarianship Conference held at California State University. Long Beach, California USA 4 - 8 August 2017. $12-21$.

Becnel, K. (2007). Sticks, Stones, and Sneering Tones: The Librarian's Role in Ending the Bullying Epidemic. Children and Libraries, 11(3), 10-15.

Crothers, S. M. (1916). A Literacy Clinic. Atlantic Monthly, 118, 291-301.

Dali, K. (2018). The lifeways we avoid. Journal of Documentation, 74(6), 1258-1273. doi:10.1108/jd-04-2018-0057.

De Vries, D., Brennan, Z., Lankin, M., Morse, R., Rix, B., \& Becl, T. (2017). Healing With Books: A Literature Review of Bibliotherapy Used With Children and Youth Who Have Experienced Trauma. Therapeutic Recreation Journal, 51(1), 48-74. doi:10.18666/trj-2017-v51-11-7652.

Dowrick, C, Billingto, J., Robinson, J., Hammer, A., \& William C. (2012). Getting reading as an intervention for common mental illness problems: Exploring catalysts for change. Medical Humanities. 38 (1), 15-20.

Harper, H. (2017) Helping students who hurt: Care based policies and practices for the school library. School Libraries Worldwide, 23 (1).

Jones, J. L. (2006). A closer look at bibliotherapy. Young Adult Library Services, 5(1), 24-27.

Orlando, J. Y. (2017). Bibliotherapy for Mental Health. International Research on Higher Education, 2(2), 67-73. doi:10.5430/irhe.v2n2p67.

Quzts, D. T., \& Palombo, M. J. (2005). Bibliotherapy and Reading. Newsletter of the Special Interest Group of the International Reading Association. 15, 1-9.

Tielsch Goddard, A. (2011). Children's Books for Use in Bibliotherapy. Journal of Pediatric Health Care, 25(1), 57-61. doi:10.1016/j.pedhc.2010.08.006.

Tukhareli, N. (2011). Bibliotherapy in a Library Setting: Reaching out to Vulnerable Youth. Partnership: The Canadian Journal of Library and Information Practice and Research, 6(1). doi:10.21083/partnership.v6i1.1402.

World Bank in Indonesia (2019) Overview https://www.worldbank.org/en/country/indonesia/overview. 
World Bank in Nigeria (2019) Overview https://www.worldbank.org/en/country/nigeria/overview.

\section{Biographies}

Dr. Fadekemi Oyewusi is a Visiting Research Scholar, Department of Interdisciplinary Professions (Library Science Program) College of Education, East Carolina University, Greenville, USA.

Dr. Maria Fe S. Nicolau has a doctorate degree in Applied Linguistics. She is currently the head librarian of BINUS School Simprug, Jakarta, Indonesia.

Dr. Kolawole Akinjide Aramide is a lecturer at Centre for Education Media Resource Studies, University of Ibadan, Nigeria.

Mrs. Francisca A. Messakh is a library consultant in Jakarta, Indonesia. 